Revue Française de Civilisation Britannique

\title{
(De)Constructing the Myth of the North in British
} Cinema (1959-2019)

Le Nord à l'écran : édification et démythification (1959-2019)

\section{Anne-Lise Marin-Lamellet}

\section{(2) OpenEdition}

\section{Journals}

Electronic version

URL: http://journals.openedition.org/rfcb/5554

DOI: $10.4000 /$ rfcb.5554

ISSN: 2429-4373

\section{Publisher}

CRECIB - Centre de recherche et d'études en civilisation britannique

Electronic reference

Anne-Lise Marin-Lamellet, "(De)Constructing the Myth of the North in British Cinema (1959-2019) », Revue Française de Civilisation Britannique [Online], XXV-2 | 2020, Online since 25 May 2020, connection on 10 December 2020. URL : http://journals.openedition.org/rfcb/5554 ; DOI : https://doi.org/ $10.4000 /$ rfcb.5554

This text was automatically generated on 10 December 2020.

Revue française de civilisation britannique est mis à disposition selon les termes de la licence Creative Commons Attribution - Pas d'Utilisation Commerciale - Pas de Modification 4.0 International. 


\title{
(De)Constructing the Myth of the North in British Cinema (1959-2019)
}

Le Nord à l'écran : édification et démythification (1959-2019)

\author{
Anne-Lise Marin-Lamellet
}

\section{Introduction}

One may say the British New Wave ${ }^{1}$ gave birth to the screen representation of the North in $1959 .^{2}$ Before that date, few films were set in the North, probably because of the lack of adequate technology to shoot on location. The adaptations of literary classics set in the north of England were entirely shot in American studios (e.g. Wuthering Heights, 1939; Pride and Prejudice, 1940; Jane Eyre, 1943). Some films with a more contemporary setting were partially shot on location (e.g. The Stars Look Down, 1940 in Cumbria, The Proud Valley, 1940 in Wales, Love on the Dole, 1941 in Blackpool), and this was used as a major promotional argument. In the late 1950s, a new generation of directors put forward another reason, a political one, to explain the relative absence of the North in films. Lindsay Anderson, the leading figure of Free Cinema and the British New Wave, wrote in a 1957 essay: "What sort of cinema have we got in Britain? First of all it is necessary to point out that it is an English cinema (and Southern English at that), metropolitan in attitude, and entirely middle-class". ${ }^{3}$ Anderson strongly opposed the increasingly irrelevant image of imperial or war heroism and advocated a radical change in the British cinema of the time. He wished to give a more accurate and contemporary representation of British society, and the North would prove a weapon of choice to achieve that goal. "Going north in Britain is always like a trip into another country [...] a real escape from the middlebrow, middle-class vacuum of the West End", ${ }^{4}$ he added, holding the view that the North was undeniably associated with authenticity and the working class. To do away with films allegedly filled with class contempt and conveying a stereotypical image of common people, the British New Wave soon offered its own view of a humanist cinema wishing to reinvent the post-war national identity, relying on the image of an urban and industrial North, home of the working class hero 
as the main character. ${ }^{5}$ It thereby started a major trend in British cinema that has continued to this day. Even though the rural North is also present on screen, it is the urban, industrial and then deindustrialised North which has prevailed since $1959 .{ }^{6}$ Over sixty years, the political and ideological representation of the North has therefore been closely connected to national identity, popular culture and cultural myths. The cinematic image of the North seems to be at the heart of two seemingly conflicting yet concurrent tendencies: the myth-making and unmaking of what still is, despite its evolution, a key component of the national imagination.

\section{Constructing the Myth of the North}

2 Although the British New Wave claimed its belief in social realism, the representation of the North on screen has given birth to a two-pronged mythical construction over sixty years. The first is a geographical one: as the cradle of the Industrial Revolution, the North has been used in films, both in times of prosperity and crisis, its natural settings outstretching its English borders to include all British industrial regions. Besides the North East and North West, the Midlands are thus fully part of the North (confirmed by Somers Town) just like the other three nations whose representation does not fundamentally differ from that of the English North. ${ }^{7}$ Films hence display a remarkable variety of large industrial and mining centres. Yet, since 1959, the North has always been a grey, urban, masculine, working-class monolith. British New Wave films invariably start with, and regularly include a long shot on terraces (Look Back in Anger) as the camera pans over potholed cobbled streets (A Taste of Honey) lined with identical houses overlooked by the nearby factory and its chimney belching dust and fumes (Saturday Night and Sunday Morning, A Kind of Loving, The Leather Boys, In Celebration). All the walls are covered with this dirt, and the sky is full of crisscrossing cables and wires as far as the eye can see. The station and gasworks are never far away (Room at the Top, This Sporting Life, Look Back in Anger). This traditional view of the North is also found in the sepia images recalling Jimmy's childhood (When Saturday Comes) or in the 1950s to 1980s period pieces (Brothers in Trouble, The Terence Davies Trilogy, Distant Voices, Still Lives, The Long Day Closes, Small Faces, Anita and Me, The Damned United, The Red Riding Trilogy, Control, '71, Believe, Pride). Other than signalling the evolution of mentalities, which led the working class to find its rightful place on screen, the rising number of period pieces about a working-class past may also signal how difficult it is for films to dispel this archetypal image of the North. ${ }^{8}$ Interestingly enough, the deindustrialisation process initiated in the 1980s has not fundamentally changed these items which have now become generic tropes. Films thus perpetuate the image of an eternal North created in the $19^{\text {th }}$ century, even though factories and mines are now closed..$^{9}$

3 The North on screen thus encompasses a rather blurred geographical area ${ }^{10}$ but one thing remains certain: going up North is like entering another country ${ }^{11}$ with its own way of life and rules according to The Red Riding Trilogy. Its imaginary borders are nonetheless clearly signposted on British motorways (In Celebration, Charlie Bubbles, For Queen and Country, The Damned United) or by the tonal change in the photography of the film, suddenly turning grey. This arguably echoes the famous expression "it's grim up north", a feeling conveyed by the Chelsea hooligan firm arriving in the outskirts of Liverpool (The Football Factory). The hero's train journey at the beginning of Get Carter is 
reminiscent of Orwell's and shows the changing landscapes as he goes from London to Newcastle, opposing an industrial and working-class North and a more rural and bourgeois/aristocratic South. The hero often seems to associate the South with stately homes (Shooting Fish, Billy Elliot, Greenfingers), so much so that Benjamin Disraeli's theory of the two nations comes to mind. ${ }^{12}$ The spatial and social distinctions tend to merge in the hero's mind, and regularly spur his proletarian consciousness over sixty years pitting the North/us vs the South/them.

4 The second mythical construction is a psychoanalytical or gendered one since the North, in direct link with its industrial past, asserts its masculine character whereas the South appeals through its feminine side. ${ }^{13}$ This myth had already been noticed by George Orwell in The Road to Wigan Pier which he called the cult of Northernness, a land where workers are all he-men and look down on their effeminate Southern counterparts. ${ }^{14}$ Landscapes look like they are built on that dichotomy: the North is covered with phallic chimneys and furnaces which are sometimes superimposed on the hero's face to better emphasise his virile omnipotence (Room at the Top) while the South reveals its curvy hills and dales. Because of this cult of rough and stubborn Northern authenticity, the Northerner was the embodiment of hyper-masculinity until the mid-1960s whereas the Southern workers seen in films looked more androgynous, effeminate or were homosexual (The L-Shaped Room, Smashing Time, Otley, Term of Trial, and more recently, Blow Dry). ${ }^{15}$ In times of crisis, the Northerner laments over the possible extinction of his species owing to the feminisation/Southernification of the country even though he supposedly remains manlier than his Southern counterpart (The Full Monty, This Year's Love). Films consistently present a frontal opposition between Northerners and Southerners, e.g. between the London choreographer and Emma's motorcycle champion father (Dream) or between the advertiser or BBC director and the Beatles (A Hard Day's Night). The hero's masculinity seems proportional to the latitude of his hometown. The evidently humorous introduction of The Battle of the Sexes describes Scotland as "one of the last bastions of man's supremacy, a man's world"; by virtue of their virility, Scotsmen are shown as the only men who can get away with wearing " the shortest skirts" aka kilts and perform folk dances reminiscent of the cancan without their sexual identity or orientation being questioned. Old MacPherson bitterly regrets sending his son to an English school whose methods he thinks are far too soft. A few decades later, Scottish Jimmy (Once Upon a Time in the Midlands) is still the most masculine-looking male around and attracts the heroine in spite of his blatant machismo whereas the other men living in the suburb of Nottingham seem by comparison so kind and gentle that they become asexual.

The cult of Northernness is strongly upheld by the South which uses it to assert its superiority, more so than by the North itself. ${ }^{16}$ The Northerner's hyper-masculinity goes hand in hand with the backward image of his region (The Battle of the Sexes, Smashing Time), all the more so as it often includes all those half-civilised peoples living in the nations formerly known as the Celtic Fringe. A proof of the anchoring of this pseudo historical myth and the deep-seated fear it generates is the pervasive threatening aspect associated with Northerners that crosses over film genres. Many British sword-and-sandal films as well as science-fiction films are based on the legendary savagery of Northerners, notably the Scots and their Pict ancestors who allegedly gave Roman legions and Vikings a hard time (The Last Legion, The Eagle of the Ninth, Valhalla Rising, Northmen - a Viking Saga). Hadrian's Wall remains a strong symbol of liminality between civilisation and ancient unchartered territory or post-apocalyptic 
barbarian land (Centurion, Doomsday) ${ }^{17}$ In thrillers or horror films, Celtic lands are those of heathen cults that are always unsettling and often prone to the human sacrifice of strangers to the community (A Lonely Place to Die, The Wicker Man, The Wicker Tree). The uncanny atmosphere of the North can be felt in the number of werewolves one can meet there (An American Werewolf in London, Dogsoldiers, Wild Country). Based on true stories (the Moors Murders, the Yorkshire Ripper) and in keeping with the Gothic tradition, the moors around northern industrial cities hide the graves of the victims of numerous sordid affairs (The Red Riding Trilogy, See No Evil: the Moors Murders). In a more social realist genre, the xenophobic commentaries heard from the upper-class and upper-middle-class characters about the (Northern) Irish bear witness to the troubled relationship between the South and its former colonies (The Boxer, Hidden Agenda). To sum up, the further up north people live, the more virile they appear to Northerners, and the more archaic to Southerners (Twin Town, The Damned United, Pride, North $v$ South, Grimsby). Paradoxically, feeling superior has not led the South to despise this traditional image of the North, which symbolises purity and authenticity. However, it does not hesitate to exaggerate, overestimate or distort Northern values to feed the myth, as shown by the commodification of the cult of Northernness (A Hard Day's Night, Prick Up Your Ears, Smashing Time, Dream, Morvern Callar). ${ }^{18}$

\section{Depicting the Reality of the North}

6 Cinema is a myth and identity maker ${ }^{19}$ but it is also a medium that has reflected the socioeconomic evolutions of the North since the late 1950s, which it uses to construct its representation. Between the late 1950s and early 1980s, the North was synonymous with relative prosperity and modernity. Whether set in actual or imaginary cities - in fact composites made of real locations - these films present an urban North that was still in keeping with the glorious past of the Industrial Revolution, as shown by the crowds of workers walking out of factories. These workers symbolise the dynamism and economic power of northern cities as well as the very strong links established within the traditional working-class community (Room at the Top, A Kind of Loving). It was also the time of post-war reconstruction as old Victorian slums were demolished by caterpillars to make way for more spacious and comfortable housing (Billy Liar). ${ }^{20}$ Streets were filled with the rumbling of machines and the laughs of building workers. The few vacant lots where children played between two building sites were soon to welcome new estates in cities looking like they were bombed because of all the roadworks, which fed the hero's fertile imagination (Billy Liar). Ingrid (A Kind of Loving) already lives in one of these new semis surrounded by a nice little garden, opening on a broad street with well cared for pavements. The sun that shines over Jenny's flowered and green estate (The Family Way) proves that one can live in an industrial town and pleasant surroundings. Films of that time testify to the development of boomtowns around regional economic hubs following the $1946 \mathrm{New}$ Town Act that created about 29 new towns to alleviate overcrowded old urban areas. The process now seems complete as suggested by the long shots over working-class residential areas (Gregory's Girl, Rita, Sue and Bob Too, Twin Town, The James Gang, A Room for Romeo Brass, Once Upon a Time in the Midlands, Ae Fond Kiss, Looking for Eric, Ratcatcher, Dream, Mischief Night, Le Donk \& Scor-zay-zee, 1 Day), or over old empty terraces and tower blocks before their final 
destruction (Ratcatcher, Looks and Smiles, The Long Good Friday, Streetlife, A Very British Gangster, Citadel, T2 Trainspotting) in more recent films.

In the 1980s, the North was hit hard by deindustrialisation and has never quite recovered ever since. It appears like a decomposing body affected by the repeated attacks of unemployment, like a recurring cancer or growing gangrene that must be cured quickly if it is to survive (Stormy Monday). Apart from very few exceptions (Twin Town, Girls' Night, Human Traffic), the deep socioeconomic changes that followed Thatcher's reforms resulted in the final collapse of that giant with feet of clay, depriving it of what made its strength and identity. Silence now reigns in deserted warehouses and in factories that are either closed down or up for sale (Business as Usual, Among Giants, The Navigators, Brassed Off, The Big Man, The Full Monty, My Son the Fanatic). Shipyards and terraces that already looked bleak enough in Get Carter are gloomier in Stormy Monday. Some working-class neighbourhoods are even close to shantytowns (Purely Belter, The Selfish Giant, Tyrannosaur, Grimsby, Wild Rose). The terraces in Cardiff and Glasgow have turned into dumps and well-known drug dens (A Way of Life, My Name is Joe, Sweet Sixteen), just like the areas ignored by tourists in Edinburgh (Trainspotting). ${ }^{21}$ Liverpool is compared to the Third World (Ladybird, Ladybird) and Grimsby said to be twinned with Chernobyl (Grimsby). Slums keep being pulled down but they are not replaced with more modern buildings and remaining wastelands further stress the endof-the-world atmosphere the hero feels (Looks and Smiles). The greyness that bathes all these towns and cities reflecting a post-industrial Britain is to be understood both in a literal and figurative sense. The dim, misty, blurred light as well as the numerous fades to black symbolise the uncertain future, the dusk or the autumn of life of the region (Letter to Brezhnev, Stormy Monday, The Full Monty, Brassed Off, Among Giants). Some films that were deliberately shot in black and white further stress this mortiferous atmosphere (Looks and Smiles, TwentyFourSeven). The imminent death of the North is symbolised by the wreath laid on the Grimley road-sign and reinforced by Danny's silicosis (Brassed Off). The scrapheaps in Streetlife are already history and the pit in Billy Elliot is living its final hours (see also Among Giants). Time is now suspended like the fixed pit wheels in Brassed off and the huge container cranes in Purely Belter. The North turns into a vast ghost-like region. Industrial cities are still haunted by a few disoriented heroes (Pontypridd in Streetlife, Crossmaheart in Divorcing Jack) but only those who cannot afford to move away stay there, like Phil (Brassed Off) who remains stuck with a mortgage in a dying town (see also My Name is Joe, TwentyFourSeven). They must face eviction and repossession once they are ruined (The Full Monty). The postindustrial North only seems to offer low-skilled jobs to the working poor (Wild Rose) and queues in front of food banks lengthen (I, Daniel Blake).

Relics of a past that no longer exists, the coalmines and factories are there to symbolise the sort of stasis affecting the North. Maybe the films shot in black and white not only symbolise the destitution of the area but also its more or less conscious museumisation. ${ }^{22}$ Although the British press regularly features articles about how some northern cities wish to get rid of that image thanks to big regeneration campaigns, applications for various sport and cultural events (Manchester and the Commonwealth Games in 2002, Liverpool as the European capital of culture in 2008) and even the financing of films presenting another image of their city, ${ }^{23}$ the cinematic representation of the North appears unchanged. However, it thus offers the perspective of those who most suffered from this brutal transformation and still exist although they are often overlooked by 
other media, people whose age-old way of life was swept away in less than two decades. Seeing all these crafts and class culture disappear or fall into oblivion fills them with melancholy and anxiety, like taxi-driver Parvez (My Son the Fanatic) and the miners in Brassed off who play on with their brass band to keep all this alive and leave a trace in history (see also The Big Man, T2 Trainspotting). Hence perhaps the aforementioned period pieces that can be then seen as sort of homage - possibly tainted with guilt - to a seriously undermined culture.

\section{Deconstructing the Myth of the North}

Alongside its social realist ambition, cinema likes to play with the myths it creates or contributes to maintain. Many films turn out to be attempts at deconstructing both the archetypal North - which ends up being geographically and socioeconomically more diverse than it first seems to be - and the figure of the Northerner - who takes the image he gives himself or that the South seeks to give him with a pinch of salt.

The contemporary and working-class North is not only synonymous with an urban and industrial world. The counterexamples set in the country or in the Lake District are rare enough (Whistle Down the Wind, Local Hero, This Filthy Earth, My Summer of Love, White Settlers, God's Own Country) but the films featuring the working class hero almost always include a scene in a more rural area. The hero's presence in this kind of environment may seem bizarre since the bucolic North is so associated in viewers' minds with heritage films - among which the famous adaptations of literary classics with the numerous versions of North and South, Pride and Prejudice, Jane Eyre, Wuthering Heights but also Women in Love, Love and Friendship - a genre that is often deemed conservative and always set in a more distant past, focusing on the lives of higher social classes. A working-class rural counterpoint is a way of showing a multifaceted North as well as placing the working class hero within a literary tradition, making him the heir of the pastoral and romanticism. Far from distorting his representation, this connection rather expresses his response to the alienation he feels due to his social condition and his fears of a potential erosion of his identity. Rural scenes often tainted with nostalgia for a preindustrial North signal the hero's unconscious fantasy over the image of a pastoral England symbolising feudal society. Forgetting his status for a moment, the Northerner becomes just a man in his natural habitat. Over sixty years, his love of nature reveals he thinks he can escape first from his harsh working conditions (Saturday Night and Sunday Morning, Kes) then the harmful effects of unemployment (TwentyFourSeven, The Angels' Share) but these rural breaks are short and ambivalent. While expressing the hero's deepest desires, they reveal personal, socioeconomic and existential tension. The only time Mrs Hammond (This Sporting Life) looks happy with Machin and her children is when they play football in front of the ruins of an old abbey. However, Machin has to go back to the city and endure the rough shocks of rugby if he wants to be able to pay for his costly Rolls-Royce trips to the country. The editing further reinforces the transience of the moment since the scene is inserted as a flashback between the party scene during which the hero suffers from broken teeth and a rugby match (see also Room at the Top, The Loneliness of the Long Distance Runner, A Taste of Honey, Kes, My Son the Fanatic, T2 Trainspotting). Nature as a form of escapism thus remains an illusion because it always sends the hero back to his condition as a worker in the end. 
11 The return to nature is even more illusory since its days are numbered. The criticism of industrialisation is certainly not new and Romantic poets were the first to lament over the consequences of the Industrial Revolution on the British landscape. ${ }^{24}$ But their complaints find an echo in those of the Northerner faced with the contemporary problem of urban sprawl. The evolution towards suburbia is felt like the destruction of his physical and social environment because gentrification and the suburbanisation of the soul seem to be inextricably linked in his mind. ${ }^{25}$ In times of relative prosperity, the changing North was not perceived positively because it was increasingly subjected to the ill-effects of its economic development (Saturday Night and Sunday Morning, A Kind of Loving). The hero remained fond of an older image of his native North with a clear separation between city and country as he saw his region look more and more like the South with pretty little residential suburbs fit for lower-middle-class workers. ${ }^{26}$ Things just got worse with time (Dead Man's Shoes). Moreover, these cheap buildings did not age well and quickly deteriorated in times of crisis turning into shabby-looking estates that cannot be redeemed by a few patches of yellow grass (Rita, Sue and Bob Too, A Room for Romeo Brass, Yasmin, Mischief Night, This is England, The Selfish Giant, Grimsby, I, Daniel Blake). Aesthetic concerns aside, this phenomenon blurring the city/country dichotomy in the hero's mind also represented his fear of embourgeoisement before symbolising his loss of social position, in other words his working-class identity. ${ }^{27}$ Yet the few films set in more rural areas show that life is just as hard there (The Holding, God's Own Country) because a beautiful landscape is not enough to feed on and locals are therefore ready to sell their acres of land to American oil executives to start a new life elsewhere (Local Hero).

12 The diversity of the North is also socioeconomic. In spite of the undesirable effects of the crisis that has reinforced the age-old North/South divide, the representation of a pauperising working-class North in more recent films (and an economically booming South) is only a global, even though largely spread, image, and some exceptions can of course be found. ${ }^{28}$ The same place can sometimes convey very different impressions: the suburbs of Nottingham in Shane Meadows's films (Small Time, A Room for Romeo Brass, Once Upon a Time in the Midlands), Edinburgh in Danny Boyle's films (Shallow Grave, Trainspotting, T2 Trainspotting) (see also Restless Natives, 16 Years of Alcohol, The Angels' Share, The Marker, I, Daniel Blake). ${ }^{29}$ There is a dichotomy between postcard images of a prosperous and touristy North (Restless Natives), like the Scottish castle overlooking a loch in Four Weddings and a Funeral, the hiking trail near Loch Lomond in Burn, Burn, Burn, the Ceilidh celebrations in the Aberdeen county in Local Hero or even small port towns like Oban in Morvern Callar, and the sink estates of Glasgow, although sometimes one just needs to cross the Clyde to find much more residential areas (Sweet Sixteen, Red Road, The Angels' Share). Wales is not merely a succession of mining valleys as shown by the region of Snowdonia (The James Gang), just like some Yorkshire towns show that coalmines or factories did not always encroach on the moor (Hebden Bridge in Fanny and Elvis, Huddersfield in Resurrected, York in Burn, Burn, Burn, Todmorden in My Summer of Love). Posh villas in the suburbs of Warnley, Manchester, Leeds, Newcastle, Sheffield or Glasgow are just as lavish as their Southern counterparts (Life at the Top, Heart, 24 Hour Party People, The Red Riding Trilogy, Get Carter, Journeyman, Wild Rose). Diversity in the North is not only a question of class struggle though: there are also interregional rivalries, reinforced by history (Boys from the Blackstuff) and football (The Damned United). 
The main deconstruction of the myth of the North comes from the irony found in these films and the Northerner himself who seems aware of this mythical construction in British society and enjoys making fun of the various images the North, whether bucolic and touristy (My Name is Joe, Trainspotting) or urban and industrial (A Taste of Honey, Billy Liar). The cult of Northernness is gently debunked with a sense of humour sometimes verging on satire or self-derision (Love Thy Neighbour, A Hard Day's Night). Charlie Bubbles plays with clichés. The Northerner who gives his name to the film is a successful novelist but also a depressive alcoholic whose brief return to his native place is above all an attempt at deconstructing the archetypal image of the industrial North seen as a relic in this swinging decade. The gasworks, the coalmine, the soon-to-be demolished terraces, the canal, the brass band, in other words all the generic tropes that the British New Wave helped launch, emphasise the feeling of terminal decline for the imagery inherited from the Industrial Revolution. Locals are not welcoming and the sequence shot at dawn conveys a very dreary image of a region trying to reinvent itself. Northern cities clearly wish to get rid of their working-class image and compete with the capital, as shown by the luxury hotel where Charlie stays. The rural North is also seen sardonically, whether it is through the cottage used as a model-farm by Charlie's estranged wife or the pan-shot on the green hills the hero gazes at in an iconoclastic way while shaving with an electrical razor plugged in the cigarette-lighter of his car. As the final escape in a hot-air balloon implies, the North is multifaceted and does not lend itself to any pigeonholing. Some more recent films seem to continue this regenerative trend by trying to convey a new, younger, more contemporary and vibrant image of the North. Without ignoring the contingencies of the film industry and a potential Trainspotting effect, ${ }^{30}$ films regularly focus on the club and rave scenes some big northern cities have been associated with. Through the portrayal of these 1990 s and 2000s subcultures, they seek to show working-class youths that unemployment or casual work do not prevent from "having it large" - though their drug use which is supposed to be recreational and hedonistic could be interpreted as a way to get away from problems and depression. Night life in these cities whose frenzy is sometimes symbolised by fast-motion sequences of constant fluxes of cars, people and shimmering lights expresses the quest for a new identity even though these subcultures are by definition not mainstream enough to represent all the Northern population (Human Traffic, Twin Town, The Acid House, 24 Hour Party People, Ecstasy, Weekender, T2 Trainspotting). Glasgow in Late Night Shopping - that focuses on the lives of young night workers - nevertheless compares favourably to London since the way it is filmed can maintain the illusion the film is set in the capital, which shows the increasing cosmopolitanism and internationalisation of some northern cities as global cities. $^{31}$

\section{Conclusion: Reconstructing the Myth of the North}

The North can thus be more diverse than its myth would have people believe but one thing unites all Northerners on screen: their aversion towards the South and everything it stands for is deeply rooted, and the rocky relationship is quite often a love-hate one. The South is always ready to deride a mythical North but the latter is just as happy to denigrate and despise its neighbour. Being a Londoner or a Sassenach is not well perceived (Withnail \& I, An American Werewolf in London, Love, Honour and Obey, 
Twin Town, Trainspotting, Restless Natives). "Southerner" even becomes an insult used by Ringo (A Hard Day's Night) and Brian Clough (The Damned United) for whom Brighton is “ almost in France". The Northerner also has a stereotypical view of the South that is generally considered to be sly, arrogant and decadent. All the films presenting a Northerner's point of view on the capital underline its artificiality whether it is through political (Dockers), media or advertising circles (Smashing Time, The Knack...and How to Get it, 24 Hour Party People). The South is dangerous for the physical and moral integrity of the Northerner. It is seen as a giant den of iniquity or a new Babylon (Naked, Somers Town), which explains the hero's reluctance to venture down South out of fear of the unknown, disinterest (Billy Elliot) or because he knows he cannot survive long out of his depth without irredeemably changing his nature. "A man can lose himself in London", Fisher (Billy Liar) likes repeating in one of his imitation games. That is why Northerners try to proudly resist the call of the capital (The Loneliness of the Long Distance Runner, When Saturday Comes) which above all wins over the hearts of Northern women, like Liz (Billy Liar), Annie (Alfie), Cathy (Cathy Come Home) or Louise (Naked). However, London turns out to be a lethal trap for these women, which reinforces the decadent image of a corrupt South (The Knack...and How to Get it, Smashing Time, Otley, Dream). ${ }^{32}$

Yet the Northerner's latent desire to go South remains significant, although his experience is ambivalent: it reveals his fascination for a place that, in the end, also undergoes a mythical (de)construction at socioeconomic and psychoanalytical levels, as a perfect counterpoint to that of the North. Over sixty years, the South is seen as a land of opportunities although it quickly turns into a fake Eldorado. This happens not only in times of prosperity, e.g. in the not so Swinging London era (A Hard Day's Night, The Knack... and How to Get it, Smashing Time, Life at the Top, Prick Up Your Ears, The Red Riding Trilogy), but also in times of crisis, when job vacancies are synonymous with working poverty, exploitation and disillusionment (Trainspotting, Naked, Riff Raff, This Year's Love, Janice Beard, 45wpm) ${ }^{33}$ and when more or less political collective trips are ignored or despised by Southern representatives (Dockers, Brassed Off, Billy Elliot). The South is also seen as a place that jeopardises the Northerner's hypermasculinity, whether it is through the meeting of women compared to praying mantises (Georgy Girl, Life at the Top, Family Life), ${ }^{34}$ the discovery of blatant homosexuality or, more generally, its supposedly devirilising customs and mores (Prick Up Your Ears, This Year's Love).

The move down South generally proving a failure, the North eventually appears like a shelter, although once again an ambivalent one. ${ }^{35}$ The northern retreat is sometimes felt like a symbolical death, the loss of all hopes (Riff Raff, This Year's Love) or points out the thwarted plans of young ambitious men (The Red Riding Trilogy). It can nonetheless be felt more positively like a return to one's roots or the community the hero should have never left (Life at the Top, Smashing Time, Wild Rose). Over sixty years, the North is always praised for its people's warmth and hospitality (Love Thy Neighbour, Naked) ${ }^{36}$ while the South stands for loneliness and a constant rush that does not allow people to forge meaningful relationships (Wonderland, This Year's Love). Besides, Southerners seem to talk a lot without saying much, which disturbs Northerners whose reputation as laconic people is just a cover for their raw sensitivity (Brassed Off, God's Own Country). Disenchanted southern experiences thus paradoxically lead Northerners to reconstruct the myth of their native North. Interestingly, the image of the North as a shelter crosses over genres since British post-apocalyptic films show that survivors often 
choose to settle up north whereas the threat comes from London (28 Days Later, Reign of Fire, Doomsday).

Over the decades, the North on screen has remained proud of its history and the imagery it has generated, mostly a grim but dignified industrial North and a beautiful but threatening rural North. With its will to construct and deconstruct the myth of the North since 1959, British cinema has clearly exploited the North/South rivalry which has become a source of creative tension. It thus keeps fuelling the debate about the North/South divide but clearly seems to have chosen its side by having firmly anchored - and popularised - a certain Northern identity at the heart of the British national culture and imagination.

\section{BIBLIOGRAPHY}

Adonis, Andrew and Pollard, Stephen, A Class Act: the Myth of Britain's Classless Society (London, Hamish Hamilton, 1997).

Ashby, Justine and Higson, Andrew (eds.), British Cinema: Past and Present (London, Routledge, 2000).

Bourke, Joanna, Working Class Cultures in Britain 1890-1960: Gender, Class and Ethnicity (London, Routledge, 1994).

Danel, Isabelle, 'Mon nom est Peter !', Télérama nº 2544 (1998), p. 32.

Davidson, Alex, Looks and Smiles, 2003-2014, available at <http://www.screenonline.org.uk/film/ id/492562/index.html>.

Disraeli, Benjamin, Sybil or the Two Nations (Harmondsworth, Penguin, 1954 [1845]).

Frodon, Jean-Michel, La Projection nationale (Paris, Odile Jacob, 1998).

Higson, Andrew, Waving the Flag: Constructing a National Cinema in Britain (Oxford, Oxford University Press, 1995).

Hill, John, British Cinema in the 1980s: Issues and Themes (Oxford, Clarendon Press, 1999).

Hjort, Mette and Petrie, Duncan (eds.), The Cinema of Small Nations (Edinburgh, Edinburgh University Press, 2007).

Iannone, Pasquale, 10 Great Films Set in Glasgow, 17 February 2015, available at <http:// www.bfi.org.uk/news-opinion/news-bfi/lists/10-great-films-set-glasgow>.

Ide, Wendy, Interview Shane Meadows: The Vision Thing, 8 March 1998, <http://

www.independent.co.uk/life-style/interview-shane-meadows-the-vision-thing-1148920.html>. Lacey, Stephen, British Realist Theatre: The New Wave in its Context (1956-1965) (London, Routledge, 1995).

Laing, Stuart, Representations of Working Class Life 1957-1964 (Basingstoke, Macmillan, 1986).

Lawrence, D.H., Selected Essays (London, Penguin, 1960 [1950]). 
Leach, Jim, British Film (Cambridge, Cambridge University Press, 2004).

Marin-Lamellet, Anne-Lise, 'Le Working Class Hero ou la figure ouvrière à travers le cinéma britannique de 1956 à nos jours', (PhD dissertation, University of Grenoble, 2011).

Maschler, Tom (ed.), Declaration (London, MacGibbon \& Kee, 1957).

McKnight, George (ed.), Agent of Challenge and Defiance, The Films of Ken Loach (Westport, Praeger, 1997).

Media Monkey, Kelvin risks northern boycott of Sun, The Guardian, 14 August 2008, available at $<$ https://www.theguardian.com/media/mediamonkeyblog/2008/aug/14/

kelvinmackenzierisksnorther>.

Moore-Gilbert, Bart and Seed John (eds.), Cultural Revolution? The Challenge of the Arts in the 1960s (London, Routledge, 1992).

Morgan-James, Annie, 'Myth and Reality: Filmic Images of Scotland', Revue française de civilisation britannique XI-2 (2001), pp. 29-40.

Orwell, George, The Road to Wigan Pier (London, Penguin, 1967 [1937]).

Petrie, Duncan (ed.), New Questions of British Cinema (London, British Film Institute, 1992).

Petrie, Duncan, Screening Scotland (London, BFI Publishing, 2000).

Richards, Jeffrey, Films and British National Identity: From Dickens to Dad's Army (Manchester, Manchester University Press, 1997).

Russell, Dave, Looking North: Northern England and the National Imagination (Manchester, Manchester University Press, 2004).

Watt, Nicholas, Tories' favourite think-tank brands northern cities failures, The Guardian, 13 August 2008, available at <https://www.theguardian.com/politics/2008/aug/13/

conservatives.regeneration>.

\section{NOTES}

1. For further details on the cycle of films made between 1959 and 1963 which focused on the lives of northern working-class people, see for example, Stephen Lacey, British Realist Theatre: The New Wave in its Context (1956-1965) (London, Routledge, 1995), pp. 163-189, and Jim Leach, British Film (Cambridge, Cambridge University Press, 2004), pp. 52-58.

2. "Screen" is understood herein as feature films since, of course, there have been short newsreels or documentaries set in the North since 1896.

3. Lindsay Anderson, 'Get Out and Push' in Tom Maschler (ed.), Declaration (London, MacGibbon \& Kee, 1957), pp. 157-160.

4. Stuart Laing, Representations of Working Class Life 1957-1964 (Basingstroke, Macmillan, 1986), p. 89.

5. The hyphenless expression is a tribute to John Lennon who invented the compound in his eponymous song. For a comprehensive definition of the phrase in the context of British cinema, see Anne-Lise Marin-Lamellet, 'Le Working Class Hero ou la figure ouvrière à travers le cinéma britannique de 1956 à nos jours' (PhD dissertation, University of Grenoble, 2011), pp. 19-33.

6. See Dave Russell, Looking North: Northern England and the National Imagination (Manchester, Manchester University Press, 2004), p. 24. 
7. The fact that these nations have had difficulties in maintaining a domestic film industry may partly explain their blending in with the rest of the British film production, which is evidently dominated by English finance as well as artistic and technical staff and thus tends to offer a metropolitan view of the country. For more details about Northern Irish and Scottish cinema, see Mette Hjort and Duncan Petrie (eds.), The Cinema of Small Nations (Edinburgh, Edinburgh University Press, 2007), pp. 60-92, and Duncan Petrie, Screening Scotland (London, BFI Publishing, 2000), pp. 1-31.

8. George Orwell, The Road to Wigan Pier (London, Penguin, 1967 [1937]), p. 101, had noticed that, whatever the evolution of the region that may make its image anachronistic, "traditions are never killed by facts". Andrew Adonis and Stephen Pollard, A Class Act: the Myth of Britain's Classless Society (London, Hamish Hamilton, 1997), pp. 184-185, mention the impact of the heritage industry that seeks to maintain the working-class history of the North and may thus explain the outdated or stereotypical image the South has about it.

9. "The recurrent image of steam trains, cobbled backstreets, gasometers and railway viaducts gave the films the feeling of taking place at the fag-end of the nineteenth century" according to Jeffrey Richards in Bart Moore-Gilbert and John Seed (eds.), Cultural Revolution? The Challenge of the Arts in the 1960s (London, Routledge, 1992), p. 220. Russell, Looking North, pp. 5 and 269, points out the fact that this traditional view of the North dates back to historians' observations of the mid to late $19^{\text {th }}$ century. He stresses the constancy of the representation of the North as "urban and industrial, grim and bleak, harsh and uncultured" over 150 years which is "remarkably similar to the pattern that was in place by about $1840 "$.

10. Many specialists have vainly tried to delimit the North. See Dave Russell, op.cit., p. xii, and Andrew Adonis and Stephen Pollard, op.cit., p. 183.

11. See Lindsay Anderson's aforementioned quote and George Orwell, The Road to Wigan Pier, p. 98.

12. Benjamin Disraeli, Sybil or the Two Nations (Harmondsworth, Penguin, 1954 [1845]), pp. 72-73.

13. This does not mean there are no strong northern women but films with a female lead role are quite rare (A Taste of Honey, Smashing Time, Letter to Brezhnev, Ladybird, Ladybird, Red Road, Wild Rose).

14. George Orwell, op.cit., p. 98.

15. One recent exception is God's Own Country that introduces a rugged homosexual Yorkshire farmer.

16. Orwell explains: "The cult is often adopted by people who are not by birth Northerners themselves". Ibid., p. 99. That may explain this mythical construction of the North on screen since most directors in the British New Wave were Southerners.

17. This symbol was used by Sun columnist Kelvin MacKenzie in 2008 following the release of a report by the Policy Exchange think-tank about the difficulties of Northern cities to regenerate. “ If it were up to me I'd get those Israeli builders to make a wall from The Wash to Bristol. They'd have it up in a jiffy", he explained so that the South could be protected from a region seen as a subsidy junkie. Media Monkey, Kelvin risks northern boycott of Sun, 14 August 2008, <https:// www.theguardian.com/media/mediamonkeyblog/2008/aug/14/kelvinmackenzierisksnorther> [8 November 2016].

18. For a detailed analysis of the South's fascination for the North, see Anne-Lise Marin-Lamellet, op.cit., pp. 448-450.

19. Because it is a powerful mode of representation, many scholars have analysed and pondered over the role of cinema vis-à-vis national identity as part of the way media not only reflect but also interact with the society of which they are the product. According to Jeffrey Richards, Films and British National Identity: From Dickens to Dad's Army (Manchester, Manchester University Press, 
1997), pp. xii and 25-26, "cinema and latterly television have played a vital role in defining, mythifying and disseminating national identity [having] functioned as propagators of the national image, both in reflecting widely held views and constructing, extending, interrogating and perpetuating dominant cultural myths". Based on the reflections of Thomas Elsaesser, "Images for Sale: The "New British Cinema" in Lester Friedman (ed.), Fires Were Started: British Cinema \& Thatcherism (Minneapolis, University of Minnesota Press, 1993), pp.59-69, the North can be seen as a myth of the nation and even a mytheme on which cinema feeds. For detailed discussions about the role of cinema in shaping, sustaining or challenging cultural identity or national myths, see Andrew Higson, Waving the Flag: Constructing a National Cinema in Britain (Oxford, Oxford University Press, 1995), pp. 4-9, 272-279; Andrew Higson, 'The Instability of the National' in Justine Ashby and Andrew Higson, (eds.), British Cinema: Past and Present (London, Routledge, 2000), pp. 35-47; Jean-Michel Frodon, La Projection nationale (Paris, Odile Jacob, 1998), pp. 19-20, 137-145; John Hill, 'The Issue of National Cinema and British Film Production' in Duncan Petrie (ed.), New Questions of British Cinema (London, British Film Institute, 1992), pp. 10-21, and Jim Leach, British Film (Cambridge, Cambridge University Press, 2004), pp. 1-17.

20. Joanna Bourke, Working Class Cultures in Britain 1890-1960: Gender, Class and Ethnicity (London, Routledge, 1994), pp. 155-156, recalls the number of rebuilding campaigns between 1945 and 1964. Adonis and Pollard, A Class Act, op.cit., pp. 200-202, list the various promises made about slum clearance throughout the $20^{\text {th }}$ century. However, there were still over 1.5 million insalubrious houses left in the mid-1990s.

21. In My Name is Joe, the used location was G12, which was initially meant to be the film title, a destitute area in Glasgow where life expectancy never exceeds 50 according to its lead actor Peter Mullan. Danel, Isabelle, 'Mon nom est Peter !', Télérama n’ 2544 (1998), p. 32.

22. The phrase was coined by famous architectural historian and conservationist James LeesMilne in his Diaries, 1942-1954 (London, John Murray, 2006), although he used it in a rather disparaging way, conservation not being synonymous with freezing time. The deliberate choice to shoot a film in black and white today can obviously be interpreted in several ways but it always makes a political or aesthetic point. The homage to earlier films or the distancing effect immediately gives a vintage or even historical aspect to the photography. Ken Loach who directed Looks and Smiles said he wanted something simple, more truthful, not pretty and strong but now thinks of it as too arty (McKnight, George (ed.), Agent of Challenge and Defiance, The Films of Ken Loach (Westport, Praeger, 1997), p.162) while critics praise it for its romanticising effect “ transforming bleak industrial backdrops into a hauntingly lyrical cityscape" (Davidson, Alex, Looks and Smiles, 2003-2014, <http://www.screenonline.org.uk/film/id/492562/index.html> [5 March 2018]). Shane Meadows who directed TwentyfourSeven insisted on the timeless quality of black and white photography (Ide, Wendy, Interview Shane Meadows: The Vision Thing, 8 March 1998, <http://www.independent.co.uk/life-style/interview-shane-meadows-the-vision-

thing-1148920.html> [5 March 2018]) thereby reaching a mythic level of eternity and thus contributing to the museumisation of the North.

23. Russell, Looking North, p. 286, speaks about the "greening" of the North after its deindustrialisation. Apparently, the Sheffield city council did not really like the publicity generated by the success of The Full Monty since the city entered the international imagination as a sort of giant industrial wasteland. Hallam, Julia, 'Film, class and national identity: re-imagining communities in the age of devolution' in Justine Ashby and Andrew Higson (eds.), British Cinema: Past and Present, pp. 262-263, 270 , explains that producing films about the North is also a way to attract investors so that they finance various regeneration projects.

24. One can think of Elizabeth Gaskell's North and South (1855) set in the imaginary region of Darkshire, the onomastics of which echoes William Blake's dark, satanic mills mentioned in 
Jerusalem (1804). Orwell, The Road to Wigan Pier, pp. 95, 100-101, calls Sheffield "the ugliest town in the Old World". He dates the origin of the North/South divide back to the Industrial Revolution.

25. Lawrence, D.H., Selected Essays (London, Penguin, 1960 [1950]), p. 121, was already complaining about the British landscape that he thought had been ravaged by these new buildings. They were not cities but endlessly sprawling suburbs, like Nottingham "an amorphous agglomeration". This town planning scheme had an impact on people's minds: "They are all suburban, pseudo-cottagy, and not one of them knows how to be truly urban".

26. Adonis and Pollard, A Class Act, pp. 188-189, beyond a Southernification of the North, mention the Americanisation of the UK that imitates its urban sprawl model.

27. For more details about how the evolution of housing has reflected and symbolised the working class hero's embourgeoisement or proletarisation over sixty years, see Marin-Lamellet, Anne-Lise, op.cit., pp. 438, 480-505.

28. Adonis and Pollard, A Class Act, p. 183, concur about the stereotypical image of a purely working-class North.

29. See Morgan-James, Annie, 'Myth and Reality: Filmic Images of Scotland', Revue française de civilisation britannique XI-2 (2001), p. 30.

30. The commercial success of that film has generated a whole batch of more or less inspired imitations, a type of formulaic cinema based on a "new sophisticated urban aesthetic, the combination of a young cast, edgy subject-matter, vibrant colours, visual pyrotechnics and a pounding soundtrack". For more details, see Petrie, Duncan, Screening Scotland, pp. 196-199.

31. The fact that Glasgow was chosen as a city double by several Hollywood majors in films such as Cloud Atlas (2012), World War Z (2013) and Fast \& Furious 6 (2013) seems to corroborate its new status. Iannone, Pasquale, 10 Great Films Set in Glasgow, 17 February 2015, <http://www.bfi.org.uk/ news-opinion/news-bfi/lists/10-great-films-set-glasgow $>$ [8 November 2016]. "Madchester" is compared to "Renaissance Florence" in 24 Hour Party People.

32. Southerners' journeys north, whether intentional or not, are rarer and often prove tragic (White Settlers, I, Daniel Blake).

33. This sort of brain drain shows that Northerners in films apply a highly controversial recommendation made in the Cities Unlimited: Making Urban Regeneration Work report by thinktank Policy Exchange that stated that many Northern cities being "beyond salvation" their inhabitants should be encouraged to move South. Watt, Nicholas, Tories' favourite think-tank brands northern cities failures, 13 August 2008, available at <https://www.theguardian.com/ politics/2008/aug/13/conservatives.regeneration $>$ [8 November 2016]. The vision of London as a second chance is often present in films although the plan to go there is not always actualised (Looks and Smiles, The Angels' Share). When it is, the vision given is biting.

34. Luckett, Moya, 'Travel and mobility: femininity and national identity in Swinging London films' in Ashby and Higson (eds.), British Cinema: Past and Present, p. 235, writes: "The heroines of the Swinging London films [...] relegate local rivalries (like the North/South divide) to a now redundant malecontrolled past [...]. London is represented as the seat of feminine power, while masculine rule is consigned to history".

35. See Russell, Looking North, p. 187.

36. Hill, John, British Cinema in the 1980s: Issues and Themes (Oxford, Clarendon Press, 1999), p. 173, confirms: "In Naked, the return to the north appears to hold out the possibility of a certain form of identity and inter-connection which is absent from the film's portrait of London as a city of lonely and alienated people". 


\section{ABSTRACTS}

The British North has featured regularly on screen since 1959. The representation of its industrial and urban features has given birth to a two-pronged mythical construction over sixty years: a geographical and a psychoanalytical/gendered one using the figure of the Northerner. Cinema is a myth and identity maker but it is also a medium which has reflected the socioeconomic evolutions of the North, first synonymous with relative prosperity and modernity until the 1980s, then decline and recession owing to deindustrialisation. Simultaneously, films try to deconstruct both the archetypal North - which ends up being geographically and socioeconomically more diverse than it first seems to be - and the figure of the Northerner - who takes his self-proclaimed image or the one that the South seeks to give him with a pinch of salt. The common identity of Northerners mostly channelled through their common aversion towards the South nonetheless leads them to reconstruct the myth of their native North.

Depuis 1959, le Nord apparaît de manière récurrente dans le cinéma britannique. À travers sa dimension industrielle et urbaine, il subit sur soixante ans une double édification mythologique d'ordre géographique et psychanalytique ou sexuel/genré en mettant en avant la figure du Northerner. Si le cinéma est un forgeur de mythe et d'identité, il ne méconnaît pas pour autant les évolutions socioéconomiques de cette région d'abord synonyme de relative prospérité et de modernité puis, à partir des années 1980, de déclin et de marasme en raison de la désindustrialisation. Parallèlement, le cinéma cherche aussi à démythifier ce Nord archétypal, finalement assez pluriel du point de vue démographique et économique, et cette figure du Northerner, peu dupe de l'image qu'il se donne ou que le Sud cherche à lui donner. Toutefois l'identité commune aux Northerners qui s'exprime par leur aversion pour le Sud conduit in fine à une forme de remythification de la région.

\section{INDEX}

Mots-clés: cinéma, classe ouvrière, Nord de l'Angleterre, homme du Nord, masculinité, mythe, désindustrialisation

Keywords: cinema, working class, Northerner, masculinity, North of England, deindustrialisation

\section{AUTHOR}

\section{ANNE-LISE MARIN-LAMELLET}

Université Jean Monnet, Saint-Étienne 